\title{
SPATIAL ANALYSIS AND RISK FACTORS OF TUBERCULOSIS IN DAIRI DISTRICT, NORTH SUMATERA
}

\author{
David Simbolon, Erna Mutiara, Rahayu Lubis \\ Masters Program in Public Health, Universitas Sumatera Utara
}

\begin{abstract}
Background: In 2016, Dairi district ranked tenth highest incidence of tuberculosis (TB) in North Sumatera. Sidikalang sub-district was the main contributor of the incidence. This study aimed to conduct spatial analysis and to determine risk factors of lung TB in Dairi district, North Sumatera.

Subjects and Method: This was a case control study carried out in Sidikalang sub-district, Dairi district, North Sumatera. A sample of 116 subjects were selected for this study consisting of 58 lung TB cases and 58 controls. The dependent variable was incidence of lung TB. The independent variables were nutritional status and smoking. Data on lung TB status was taken from the medical record. The other data were collected by questionnaire. The data were analyzed by a spatial analysis and a multiple logistic regression.

Results: There was a lung tuberculosis cluster in Sidikalang sub-district, North Sumatera, with cluster center located at 2.739740 North Longitude, 98.324160 East Longitude. Poor nutritional status $(\mathrm{OR}=19.91 ; 95 \% \mathrm{CI}=6.99$ to 56.77 ; $\mathrm{p}<0.001)$ and smoking $(\mathrm{OR}=3.72 ; \mathrm{CI}=1.11$ to $12.82 ; \mathrm{p}=0.037)$ were associated with an increased risk of lung TB.

Conclusion: Poor nutritional status and smoking are associated with an increased risk of lung TB.
\end{abstract}

Keywords: lung tuberculosis, nutritional status, smoking, cluster, spatial analysis

\section{Correspondence:}

David Simbolon. Masters Program in Public Health, Universitas Sumatera Utara, Jln. Martabe No.24 Kec. Sidikalang, Kab. Dairi 22212, North Sumatera.

Email: davidsimbolon84@gmail.com. Mobile: 082277194565.

The 4th International Conference on Public Health

Best Western Premier Hotel, Solo, Indonesia, August 29-30, 2018 | 44 https://doi.org/10.26911/theicph.2018.01.05 